\title{
Beyond Propaganda: Soviet Active Measures in Putin's Russia
}

\section{Steve Abrams}

\begin{abstract}
This paper investigates the role of Soviet-style "active measures" as an element of modern Russian "political warfare." These techniques were commonly used during the Soviet-era, encompassing a broad range of influence activities, including: covert media placement, forgery, agents of influence, "friendship" societies, front organizations, and more. Today, in Putin's Russia, these active measures are once again in use, updated for digitally interconnected "global information space." The paper begins with an introduction to active measures, then discusses their role in Soviet foreign policy and the attempts by the American "Active Measures Working Group" to counter them. The paper then describes how the Soviet active measures playbook has been updated for the modern era, using three case studies as examples. The paper concludes with a discussion on strategy, reproducing a number of recommendations from key publications.
\end{abstract}

Keywords: active measures, agent of influence, deception operations, disinformation, hybrid warfare, subversion, KGB, Russia, Siloviki.

\section{Preface: An Awakening}

The neatest trick of the devil is to persuade you that he does not exist. - Charles Baudelaire, $1869^{1}$

They began to appear in late February 2014. Equipped with the latest military weapons and gear, stripped of identification and riding unmarked military vehicles, they rapidly seized ground. ${ }^{2}$ While the world looked on in confusion, in a few weeks it was over; Crimea belonged to the Little Green Men.

1 Charles Baudelaire, Paris Spleen: Little Poems in Prose, trans. Keith Waldrop (Middletown, CT: Wesleyan University Press, 2009), 60.

2 Arto Pulkki, “Crimea Invaded by High Readiness Forces of the Russian Federation," 
Several months later, on a beautiful July afternoon, a shower of composite and aluminum aircraft parts suddenly darkened the blue skies of Eastern Ukraine, raining down upon the sunflower fields near Hrabove. The 298 passengers and crew of Malaysia Airlines Flight 17 were all killed when their Boeing 777 was struck by a Russian-made 9M38 missile, launched by a Buk-M1 anti-aircraft system. ${ }^{3}$ At over 18 feet long, the missile was nearly the size of a telephone pole, and traveling three times the speed of sound.

Screened by a schizophrenic torrent of state-sponsored propaganda, the Kremlin maintained innocence, distancing Russia from the controversial events and vehemently denying involvement - despite mounting evidence to the contrary.

For many Western audiences, their first introduction to modern Russian propaganda was the frenetic spin cycle surrounding these dramatic events. Described as "darkly, nastily brilliant" and "so much more sophisticated than Soviet propaganda," in the year and a half since Crimea's illegal referendum on independence, journalistic observation and scholarly analysis of the RT television network (formerly Russia Today) and others have helped raise awareness of the Kremlin's coordinated manipulation of Russian mass media. ${ }^{4}$

Unfortunately, RT and other state-controlled media outlets represent only one facet of a much larger influence campaign - a single tool in a range of understudied activities that constitute a concerning gap in the West's broader "soft-containment" of Putin's Russia.

\section{An Introduction to "Active Measures"}

In short, the Soviet approach to international relations can perhaps best be described as a form of "political warfare," with the manipulative and deceptive techniques of active measures playing an essential and important role.

— USIA Report, Soviet Active Measures in the "Post-Cold War" Era, 1988-1991

Suomen Sotilas, 3 March 2014.

3 Nick Miller, "MH17 Plane Was Shot Down by a Buk Missile, Russian Weapons Manufacturer Says," The Age, 3 June 2015, available at www.theage.com.au/world/mh17plane-was-shot-down-by-a-buk-missile-russian-weapons-manufacturer-says-

20150602-ghfdco.html (accessed 9 August 2015); Dutch Safety Board, Crash of Malaysia Airlines Flight Mh17 (The Hague: Dutch Safety Board, 2015), 9, available at http://onderzoeksraad.nl/en/onderzoek/2049/investigation-crash-mh17-17-july2014 (accessed 11 February 2016).

4 David Remnick quoted by Peter Pomerantsev and Michael Weiss, The Menace of Unreality: How the Kremlin Weaponizes Information, Culture and Money (New York, NY: The Institute of Modern Russia, 2014), 14.

5 United States Information Agency, Soviet Active Measures in the "Post-Cold War" Era (Washington, D.C.: 1992), available at http://intellit.muskingum.edu/russia_folder/ pcw_era/index.htm\#Contents (accessed 19 August 2015). This document is digitally archived in hyperlinked sections. This quote appears in the section titled "The Role of Active Measures in Soviet Foreign Policy." 
The Russian Federation is currently waging "the most amazing information warfare blitzkrieg ... in the history of information warfare," pursuing a revanchist foreign policy considered by senior diplomatic and military leaders to be a tremendous security threat for both Europe and America. ${ }^{7}$ While many in the West are by now familiar with Russia's infamous RT network, its state-sponsored media outlets are only the tip of the iceberg - the "white propaganda" component of a much broader system of influence activities designed to shape the global information space.

With roots in Leninist thinking, over generations the Soviets mastered a range of techniques known as aktivnyye meropriyatiya, or "active measures," ranging from simple propaganda and forgery to assassination, terrorism and everything in between. In the West, these politics by other means were simply referred to as "dirty tricks." 8

Described by Major General Oleg Kalugin, the KGB's highest ranking defector, as "the heart and soul of Soviet intelligence," these "active measures were well integrated into Soviet policy and involved virtually every element of the Soviet party and state structure, not only the KGB." ${ }^{9}$ As a major component of

6 Ibid., Quote appears in section titled "The Soviet View of Compromise and Conciliation."

7 Michael Birnbaum, "Fearing Russian Expansion, Baltic Nations Step Up Military Exercises," The Washington Post, 16 May 2015, www.washingtonpost.com/world/ europe/fearing-russian-expansion-baltic-nations-step-up-military-exercises/2015/ 05/15/b5ee51ee-f8c8-11e4-a47c-e56f4db884ed_story.html (accessed 17 May 2015); Ian Johnston, "'Russia's Growing Threat: After Ukraine, Fears Grow That Baltic States Could Be Vladimir Putin's Next Targets," The Independent, 8 February 2015, http://www.independent.co.uk/news/world/europe/russias-growing-threat-afterukraine-fears-grow-that-baltic-states-could-be-vladimir-putins-next-targets10032378.html (accessed 19 August 2015); Jamie Crawford, "Joint Chiefs Nominee: Russia Greatest Threat to U.S.," CNN Politics, 10 July 2015, www.cnn.com/ 2015/07/09/politics/joseph-dunford-russia-greatest-threat/index.html (accessed 17 August 2015).

8 "Soviet Active Measures," YouTube video, 23:31, posted by PublicResourceOrg, 9 December 2010, https://www.youtube.com/watch?v=Z-X_bXL2Tgo (accessed 19 August 2015).

9 "Inside the KGB - An interview with retired KGB Maj. Gen. Oleg Kalugin," Cold War Experience, CNN, January 1998, http://web.archive.org/web/20070627183623/ http://www3.cnn.com/SPECIALS/cold.war/episodes/21/interviews/kalugin (accessed 8 July 2015). While some consider Kalugin a controversial figure, where referenced in 
Soviet foreign policy, these tactics were incredibly well resourced. According to experts, the "Soviet active measures apparatus dwarfed, by a factor of perhaps 20 or 30 to one, the US governmental apparatus set up to analyze and counter its activities." ${ }^{10}$ At their peak, it is estimated that the Soviet active measures campaign employed up to 15,000 people - more than the number of diplomats serving in the post-9/11 US Department of State. ${ }^{11}$

Even at the height of the Cold War, despite their massive scale, the use of these programs by the Soviet Union was not well understood, and today, broadly addressed under the ambiguous labels of "hybrid warfare" and "malign influence," these techniques are even less understood, and their use largely forgotten - relics of the Cold War. ${ }^{13}$

Unfortunately, it is becoming clear that Soviet-era active measures are alive and flourishing in

I would describe it as the heart and soul of the Soviet intelligence - was subversion. Not intelligence collection, but subversion: active measures to weaken the West, to drive wedges in the Western community alliances of all sorts, particularly NATO, to sow discord among allies, to weaken the United States in the eyes of the people of Europe, Asia, Africa, Latin America, and thus to prepare ground in case the war really occurs. To make America more vulnerable to the anger and distrust of other peoples.

Oleg Kalugin, KGB Major General (retired) ${ }^{12}$ Putin's Russia. Enabled by technology and adapted for a globalized world, their modern incarnations are much more sinister, with far greater range and speed - and, through the Internet, able to influence popular opinion on a scale never before possible.

Through the European Reassurance Initiative and Operation Atlantic Resolve, US and NATO allies are working to deter Russian military aggression along the Alliance's flanks. ${ }^{14}$ Sector-based and individually-targeted economic

this document, his quotes comport with a number of other firsthand accounts by KGB defectors; Thomas Boghardt, "Operation INFEKTION: Soviet Bloc Intelligence and Its AIDS Disinformation Campaign," Studies in Intelligence 53:4 (December 2009), 1-2.

10 Soviet Active Measures in the "Post-Cold War" Era. Quote appears in section titled "White or Overt Active Measures."

11 Pomerantsev and Weiss, The Menace of Unreality, 8; Matthew Asada, Susan Johnson and Cameron Munter, "Diplomacy Post-9/11: Life in the US Foreign Service," interview by Kojo Nnamdi, The Kojo Nnamdi Show, 22 September 2011, http://thekojonnamdishow.org/shows/2011-09-22/diplomacy-post-911-life-us-

foreign-service (accessed 19 August 2015). The 15,000 figure is referenced by Pomerantsev and Weiss, and the number of post-9/11 diplomats comes from Kojo Nnamdi's interview.

12 "Inside the KGB."

13 Dennis Kux, "Soviet Active Measures and Disinformation: Overview and Assessment," Parameters, Journal of the US Army War College 15:4 (Winter 1985), 19.

14 US European Command Communication and Engagement Directorate, "Operation Atlantic Resolve Fact Sheet," 19 February 2015. 
sanctions have been imposed on Russia by the US and the EU. ${ }^{15}$ Western awareness of Russian propaganda is steadily growing, and steps are slowly being taken on both sides of the Atlantic to reduce the effectiveness and reach of the campaign. ${ }^{16}$

Despite efforts to mitigate Russia's military threat on one end of the spectrum and a white propaganda campaign on the other, publicly at least, the "gray area" in the middle remains largely unaddressed. This is key terrain - the battleground for active measure campaigns.

While the "means" have been updated for today's environment, strikingly close parallels may be drawn between the "ends" and "ways" of the Soviet active measures playbook and the "malign influence" of Putin's Russia.

By studying the exceptional and forgotten work of America's Cold War experts, and updating and adapting their 30-year-old lessons, today's security professionals and journalists can more easily identify and expose Putin's "dirty tricks."

\section{Historical Background: President Reagan and the Active Measures Working Group}

On January 20, 1981, Ronald Reagan was sworn in as the $40^{\text {th }}$ President of the United States, beginning the first of two terms and opening the final chapters of the Cold War. Reagan's plan to end the conflict would be detailed in 1983 in National Security Decision Directive (NSDD) 75, but he had defined his vision years earlier. ${ }^{17}$ In a 1977 conversation with Richard V. Allen, his chief foreign policy advisor, Reagan stated plainly, "My idea of American policy toward the Soviet Union is simple ... We win and they lose." 18

A profound shift from containment and détente, the Reagan Doctrine, as the strategy outlined in NSDD 75 became known, took a much more aggressive stance toward the Soviet Union. Designed to "accelerate the demise of the Soviet Union," and "roll back" Soviet influence throughout the world, NSDD 75

15 "Ukraine Crisis: Russia and Sanctions," BBC News, 19 December 2014, http://www.bbc.com/news/world-europe-26672800 (accessed 19 August 2015).

16 Bill Gertz, "House Adds Funds to Counter Russian Info War," Washington Times, 29 April 2015, http://www.washingtontimes.com/news/2015/apr/29/inside-the-ringhouse-funding-bill-targets-russian/? (accessed 19 August 2015); "Lithuania to Ban Russian TV Channel for 'Warmongering,'” Deutsche Welle, 8 April 2015, http://www.dw.com/en/lithuania-to-ban-russian-tv-channel-for-warmongering/a18370852 (accessed 19 August 2015).

17 Norman A. Bailey, The Strategic Plan That Won the Cold War: National Security Decision Directive 75 (MacLean, VA: The Potomac Foundation, 1998).

18 Richard V. Allen, "The Man Who Won the Cold War," Hoover Digest, 30 January 2000, http://www.hoover.org/research/man-who-won-cold-war (accessed 6 August 2015). 
offered clear strategic guidance and resulted in the broad implementation of new initiatives across all instruments of national power. ${ }^{19}$

Easily overlooked amid this transformation and lost in the high-stakes drama of the Reagan years was the formation of a small "part-time interagency committee" known as the Active Measures Working Group (AMWG). ${ }^{20}$ Established in the summer of 1981 and producing a final report in 1992, the group operated for eleven years at the height of the Cold War, with the collapse of the Soviet Union ultimately signaling its end. ${ }^{21}$ Originally headed by Deputy Assistant Secretary of State Dennis Kux and nested under the US State Department's Intelligence and Research Bureau, the group included stakeholders from numerous agencies, including the Department of State (DOS), Department of Defense (DOD), Central Intelligence Agency (CIA), Defense Intelligence Agency (DIA), Federal Bureau of Investigation (FBI), Department of Justice (DOJ), Arms Control and Disarmament Agency (ACDA - later folded into State), and the (now defunct) US Information Agency (USIA). ${ }^{22}$

The mission of the AMWG was to identify and expose Soviet disinformation. ${ }^{23}$ In their comprehensive study of the group, Schoen and Lamb write:

The group successfully established and executed US policy on responding to Soviet disinformation. It exposed some Soviet covert operations and raised the political cost of others by sensitizing foreign and domestic audiences to how they were being duped. The group's work encouraged allies and made the Soviet Union pay a price for disinformation that reverberated all the way to the top of the Soviet political apparatus. It became the US Government's body of expertise on disinformation and was highly regarded in both Congress and the executive branch. $^{24}$

\section{What's in a Name? Defining the Scope of Soviet Active Measures}

One way of looking at the impact of these activities... is to think of drops of water falling on a stone: five minutes, ten minutes, fifteen minutes, one hour, one day, nothing happens, but five years, ten years, fifteen years - you've worn a hole in the stone.

19 Bailey, The Strategic Plan.

Fletcher Schoen and Christopher J. Lamb, Deception, Disinformation, and Strategic Communications: How One Interagency Group Made a Major Difference (Washington, DC: National Defense University Press, 2012), 3.

21 Ibid. In 1992 the United States Information Agency published what appears to be the final publicly available US Government report on Active Measures, titled "Soviet Active Measures in the 'Post-Cold War' Era 1988-1991." While the report was officially published by USIA and clues to specific authorship are not available, it is almost certain that this document was produced by former AMWG experts as the organization was restructured and disbanded in the wake of the Cold War. Ibid., 35.

23 Ibid., 4-5.

24 Ibid., 3. 
- Dennis Kux, Former Head of the Active Measures Working Group, $1984{ }^{25}$

"The term active measures... was a catchall expression used by the KGB for a variety of influence activities." ${ }^{26}$ In practice however, offering a more exact definition is difficult, for according to former US Under Secretary of State Lawrence Eagleburger, "no phrase in English conveys precisely the meaning of active measures." 27

For the interagency stakeholders of the AMWG-America's Cold War experts on the subject-arriving at a consensus definition proved exceedingly challenging. ${ }^{28}$ In essence, the term embodied a range of activities limited only by the imagination and creativity of the KGB's half-million officers, and could include anything from simple propaganda to kidnapping, murder, drug trafficking, and the illicit support of terrorism. ${ }^{29}$ Throughout its existence, members of the AMWG grappled over the nebulous definition of phrase: "State and CIA, for different reasons, wanted the term defined more narrowly," while "others defined active measures much more broadly to include overt propaganda, covert action, strategic deception, and other types of political warfare." ${ }^{30}$ Schoen and Lamb explain:

KGB influence activities did include setting up and funding front groups, covert broadcasting, media manipulation, disinformation and forgeries, and buying agents of influence. However, this understanding of active measures is too narrow. Soviet active measures went beyond overt and covert operations to manipulate perceptions and into the realms of incitement, assassination, and even terrorism. Soviet leaders made no major distinction between overt propaganda and covert action or between diplomacy and political violence.

In practice, they all were tightly controlled by the Politburo and Secretariat of the Communist Party of the Soviet Union, which approved the major themes of active measures operations. ${ }^{31}$

Eventually, the difficulty of responding to such a broad range of activity resulted in the creation of a classified spin-off group "that operated out of the National Security Council (NSC) staff... us[ing] a wider range of methods and address[ing] a broader set of Soviet active measures than the group at State." 32

25 "Soviet Active Measures," YouTube video. Schoen and Lamb, Deception, Disinformation, and Strategic Communications, 66-67.

"The Making of a Neo-KGB State," The Economist, 23 August 2007, http://www.economist.com/node/9682621 (accessed 11 August 2015); Brian Crozier, "The Other Side of Perestroika: The Hidden Dimension of the Gorbachev Era," Demokratizatsiya 4:1 (1996), 48-49. The 500,000 figure appears in The Economist, and Crozier describes KGB involvement in drug trafficking.

30 Schoen and Lamb, Deception, Disinformation, and Strategic Communications, 66-67.

31 Ibid., 8.

32 Ibid., 8. 
While it is assumed that the classified group at NSC handled more kinetic and clandestine active measures, the unclassified working group remained focused solely on exposing Soviet disinformation. By limiting "its mission to countering Soviet influence operations that could be exposed in a compelling way with unclassified or declassified information" and "delineat[ing the mission] in a practical way, the group could hold itself accountable for identifying disinformation problems, finding ways to resolve them, and producing actual results." ${ }^{33}$ Further, "the group's modest definition of purpose and holistic approach to the mission allowed it to concentrate on cases that were likely 'winners' and to do so with few resources, which made cooperation from parent organizations more likely." 34

The concept of active measures, then, offered by the State Department's AMWG provides the best basis for an unclassified, open source examination of the issue, and a starting point for efforts to analyze and expose Russian active measures in the current operating environment.

Writing in a 1985 volume of the US Army War College Journal, Parameters, Dennis Kux elaborates on this concept, providing perhaps the best framework for understanding Soviet active measures - one that easily applies to contemporary analysis:

[Consider] the whole spectrum of Soviet foreign policy endeavors through the optic of "white," "gray," and "black" operations. Normal diplomatic, trade, aid, and informational efforts can be considered "white" or overt activities. "Gray" activities are those involving communist fronts, foreign communist parties, "clandestine" radio stations, or well-known media outlets for disinformation. While not officially acknowledged to be Soviet sponsored, semiovert "gray" activities are widely known as under Soviet direction and control. In contrast, "black" activities involve genuinely clandestine operations: the use of agents of influence, spreading false rumors, duping politicians

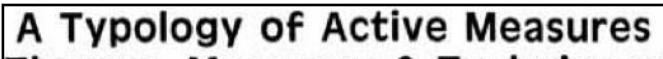
Themes, Messages \& Techniques

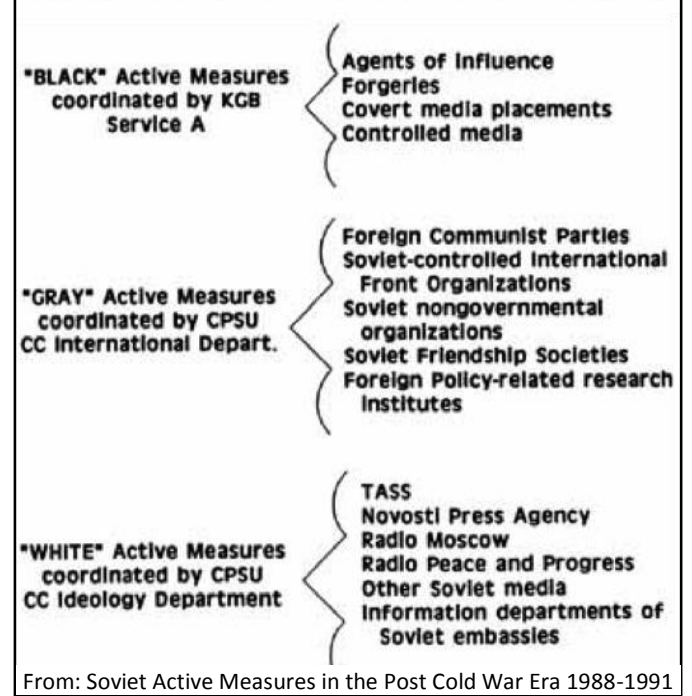
and journalists, and disseminating

33 Ibid., 4-5.
34 Ibid., 5. 
forgeries and fake documents. Active measures fall under either the "gray" or the "black" rubric, although the line ... is often blurred. ${ }^{35}$

A 2009 volume of the CIA's professional journal, Studies in Intelligence, explains that two primary categories of active measures were in use during the Soviet Era, and describes their implementation:

1) Center gives strategic go-ahead for a disinformation campaign.

2) Ideas would be generated by residency officers assigned to read local press, books, and magazines for material that could be used for disinformation purposes.

3) Center would evaluate the ideas.

4) Still at the Center, preparation involved disinformation specialists writing in their native language, approvals by managers, and translation.

5) Targeting followed. The Center typically sought to launch a story outside the Soviet bloc-controlled press to conceal Moscow's hand. This was done frequently through anonymous letters and newspaper articles in the Third World.

6) Once published abroad, the Soviet media might pick up and further propagate the item by referring to its non-Soviet source.

The first category includes operations initiated and designed within KGB ranks and usually employs such traditional disinformation techniques as forgeries or agents of influence. The KGB conducts hundreds of these categories every year even though their impact is rather limited.

The second type was the result of a strategic decision at the top of the Soviet active measures pyramid and directly approved by the Politburo. Campaigns were usually planned to last several years and encompassed many elements of the Soviet state, including the International Information Department (IID), which directed official press organs, such as TASS, Novosti, and Radio Moscow; and the International Department (ID), responsible for liaison with foreign communist parties, international communist front organizations, and clandestine radios.

The KGB, ID, and IID would cooperate closely in executing a particular campaign with the means available to each - the KGB's Service A, responsible for forgeries and spreading rumors ("black propaganda"), the IID's press organs for official stories ("white propaganda"), the ID for clandestine radio broadcasts and the use of international front organizations ("gray propaganda"). ${ }^{36}$

A growing body of evidence suggests that a very similar system of top-down control over Russian disinformation efforts is still in use by the Kremlin today, with journalist Peter Pomerantsev and a number of other former Russian media insiders describing their personal experiences from within the system. Rus-

35 Kux, "Soviet Active Measures and Disinformation," 19.

36 Boghardt, "Operation INFEKTION: Soviet Bloc," 3. 
sia's disinformation campaigns, like the Soviet Union's, appear to be coordinated and controlled at the highest levels of Kremlin leadership. ${ }^{37}$

\section{What's Past is Prologue}

The USIA published a final report on active measures in 1992, but not because Kremlin influence campaigns had ceased to exist. ${ }^{39}$ The report, titled "Soviet Active Measures in the Post-Cold War Era 1988-1991," highlights a number of interesting phenomena that took place at the twilight of

Both the hard-line former communist forces and the Russian Government are engaged in active measures and disinformation operations, in the quest to achieve their political goals. Both groups should be expected to continue to pursue such operations vigorously.

Until and unless a truly democratic regime that fully embraces Western ideals of truth, honesty, openness, and mutual advantage emerges in Russia, those in power or contending for power there will, most likely, find it to their advantage to continue active measures and disinformation operations.

- USIA Report, Soviet Active Measures in the "Post-Cold War" Era, 1988-1991 ${ }^{38}$ the USSR.

Following the Cold War's end, while the use of "crude, anti-American disinformation" waned, the KGB's active measures apparatus refocused its efforts, ratcheting up attacks on a range of new targets. ${ }^{40}$ As the collapse of the Soviet Union neared, new influence campaigns focused on ensuring the survival of the Soviet status quo and preserving existing power structures.

Entering the 1990s, the KGB not only intensified its "defamatory disinformation against ... domestic adversaries" of the Soviet Communist Party, but also "launched a major active measures campaign designed to create a benign, and false, image of the KGB." ${ }^{41}$ Regarding the West, "Soviet authorities deliberately sought to influence Western policy" by spreading "alarmist active measures themes energetically as they attempted to turn to their advantage Western fears about the dangers of a break-up of the USSR." ${ }^{42}$

Unfortunately, the 1992 report by the AMWG would be the last of its kind, and the authors were clearly well aware of this. With this apparent, they of-

37 Carl Schreck, "Russian TV Deserters Divulge Details On Kremlin's Ukraine 'Propaganda,'" Radio Free Europe/Radio Liberty, 7 August 2015, www.rferl.org/ content/russian-television-whistleblowers-kremlin-propaganda/27178109.html (accessed 12 August 2015); Pomerantsev and Weiss, The Menace of Unreality.

38 Soviet Active Measures in the "Post-Cold War" Era. Quote appears in section titled "Looking to the Future."

39 See footnote 21.

40 Soviet Active Measures in the "Post-Cold War" Era. Quote appears in section titled "Crude, Anti-American Disinformation."

41 Ibid. Quote appears in section titled "Executive Summary."

42 Ibid. Quote appears in section titled "Executive Summary." 
fered a number of predictions and warnings about the continued use of active measures by the new Russia and its former constituent states, stating that "many large fragments of the Soviet active measures apparatus continue to exist and function, for the most part now under Russian rather than Soviet sponsorship." ${ }^{43}$

In the wake of the Cold War and with the "Red Menace" defeated, Western attention would largely shift away from the former Soviet Union - now free to focus elsewhere. The West began to cut military spending, slashing programs and shedding experts and infrastructure deemed obsolete, with the savings earmarked for new domestic priorities - the so-called Peace Dividend.

With the threat of nuclear war averted, in the 90s a new range of conflicts and threats emerged to capture America's attention: Saddam Hussein's 1990 invasion of Kuwait and the subsequent Operations Desert Storm and Desert Shield, a decade of conflict and genocide in the former Yugoslavia, and the ascendancy of Al-Qaeda and the "new" threat of terrorism, as witnessed in the 1993 World Trade Center bombing, the 1995 Oklahoma City bombing, the 1996 Centennial Park bombing, the 1996 Khobar towers bombing, and the 1998 bombings of US Embassies in Tanzania and Nairobi.

Meanwhile, with the KGB and its tools of "political warfare" seemingly consigned to the history books, a new, capitalist Russia was emerging from the ashes of the Soviet Union, with powerful oligarchs siphoning away state resources and creating a system of "kleptocracy," birthing a "mafia state" that would lead Russia into the era of Putinism. ${ }^{44}$

\section{The Power Vertical: Vladimir Putin and the Siloviki}

There is no such thing as a former KGB man. - Vladimir Putin, $2006^{45}$

Growing up in post-war Leningrad and "influenced by films and books," young Putin became enamored with the world of espionage, setting his sights on a career with the KGB. ${ }^{46}$ After completing university in 1975, he officially joined its ranks, launching a 16-year career and attaining the rank of lieutenant colonel

43 Ibid. Quote appears in section titled "Executive Summary."

44 David Remnick, "Watching the Eclipse," The New Yorker, 11 August 2014, http://www.newyorker.com/magazine/2014/08/11/watching-eclipse (accessed 19 August 2015); "Wikileaks: Russia Branded 'Mafia State' in Cables," BBC News, 2 December 2010, http://www.bbc.com/news/world-us-canada-11893886 (accessed 19 August 2015).

45 Quoted in Anna Nemtsova, "A Chill in the Moscow Air," Newsweek, 5 February 2006, http://www.newsweek.com/chill-moscow-air-113415 (accessed 19 August 2015).

46 Quoted in "Vladimir Putin: Biography," Vladimir Putin Personal Website, http://eng.putin.kremlin.ru/bio (accessed 19 August 2015); Masha Gessen, "Portrait of the Young Vladimir Putin," Newsweek, 2 February 2012, www.newsweek.com/ portrait-young-vladimir-putin-65739 (accessed 11 August 2015). 
before ostensibly leaving the service in $1991 .^{47}$ After the KGB, he entered politics, serving as Deputy Mayor of St. Petersburg until $1996 .^{48}$ In July 1998, he returned to the security services, where he was appointed Director of the Federal Security Service (FSB) by President Boris Yeltsin - putting him in charge of the KGB's closest post-Soviet successor. ${ }^{49}$

Putin's official Kremlin biography offers a rather bland overview of his intelligence career, a chronology that minimizes his achievements and contrasts with a number of accounts - some of which claim "that Putin was deeply involved in several of the KGB's highest priority operations through the $1980 \mathrm{~s}$ and into the 1990s." 50

For "the man without a face" (to borrow from journalist Masha Gessen), an accurate, open source account of his time with the KGB may never come to light, and the truth of Putin's past will likely remain within the realm of speculation. ${ }^{51}$ What seems clear, however, is that he served with the KGB's First Chief Directorate (responsible for foreign intelligence) at the height of the Cold War, during a period that overlapped with the existence of the US State Department's AMWG.

As an officer in the Soviet-era First Chief Directorate, Putin would have been "expected to spend 25 percent of his time conceiving and implementing [active measures]." 52 He would have first learned to wield these skills in 1975 during initial training and indoctrination at KGB School \#1, and they would have been reinforced in Moscow in 1984 during his studies at the KGB's elite Andropov Red Banner Institute. ${ }^{53}$ After serving 16 years with the $K G B$, and later as head of the FSB, there can be no doubt that Putin is well-trained in the use of active measures as a foreign policy tool - as were all KGB officers of his era.

Since his appointment as acting president in 1999, Putin has systematically consolidated power, placing an expansive network of trusted friends and security service veterans into positions of great influence throughout the government and Russian society at large. ${ }^{54}$ This system has become known as the

47 “Russia 2000 Part 2: The Face of Russia to Come," Stratfor Global Intelligence, 11 October 1999, https://www.stratfor.com/sample/analysis/russia-2000-part-2-facerussia-come (accessed 15 August 2015).

48 "Vladimir Putin: Biography;" "Russia 2000 Part 2;" Gessen, "Portrait of the Young Vladimir Putin."

49 Ibid.

50 "Russia 2000 Part 2."

51 Cf. Masha Gessen, The Man Without a Face: The Unlikely Rise of Vladimir Putin (New York: Riverhead, 2012).

52 Boghardt, "Operation INFEKTION: Soviet Bloc," 1.

53 "Vladimir Putin: Biography;" "Russia 2000 Part 2;" Gessen, "Portrait of the Young Vladimir Putin."

54 Andrei Illarionov, "The Siloviki in Charge," Journal of Democracy 20:2 (April 2009): 70-71. 
"Power Vertical," and its strongmen the "siloviki," or "power guys." ${ }^{55}$ These socalled "securocrats" "reach ... into all areas of Russian life. They can be found not just in the law-enforcement agencies but in the ministries of economy, transport, natural resources, telecoms and culture. Several KGB veterans occupy senior management posts in Gazprom, Russia's biggest company, and its pocket bank, Gazprombank." ${ }^{56}$ Providing an eye-opening assessment of this phenomenon, in 2006 researcher Olga Kryshtanovskaya found that nearly $80 \%$ percent of Russia's elite have ties to the security services. ${ }^{57}$ It thus appears that Putin has truly created a "neo-KGB state." 58

Furthermore, Putin has now been at the top of the Russian Federation for more than 15 years, in 2008 flip-flopping with Dmitry Medvedev for a brief stint as prime minister before returning to the presidency through a slick interpretation of the Russian constitution. After Medvedev's 2008 extension of presidential term limits to six years, even without further constitutional manipulation, Putin could conceivably remain president of the Russian Federation until 2024 - outlasting Barack Obama and possibly the next two US presidents. ${ }^{59}$

With the likelihood of Putin's continued reign combined with the potential longevity of his vast siloviki network (which will likely far outlive the Putin era), it seems certain that active measures will continue to play a key role in Russian foreign policy well into the foreseeable future. With the hopeful "reset years" now a distant memory, the West must recognize the important role of active measures in Russian foreign policy, taking immediate steps to raise awareness and blunt the effectiveness of these "dirty tricks" in the modern era.

\section{Everything Old is New Again}

Following the dissolution of the AMWG, concrete, verifiable evidence of Russian active measures becomes much harder to expose, and the extent of their use in the 90s remains largely unknown. Reports of their use began to increase, however, after Putin came to office in 1999.

Open-source assertion that Russia was once again using active measures as a component of foreign policy came in the 2008 annual report of the Czech Security Information Service - equivalent to the US's FBI. The authors state unequivocally that the "operations of intelligence services of the Russian Federation ... are by far the most active ones in our territory. The assumption that Russia readopted the Soviet practice of using active measures to promote its

55 "The Making of a Neo-KGB State."

56 The phrase securocrats appears in Illarionov, "The Siloviki in Charge," 69; "The Making of a Neo-KGB State" describes their reach.

57 "Russia: Expert Eyes Security Ties Among Siloviki," Radio Free Europe / Radio Liberty, http://www.rferl.org/content/article/1073593.html (accessed 26 July 2015).

58 "The Making of a Neo-KGB State."

$59 \mathrm{Jim}$ Nichol, Russian Political, Economic, and Security Issues and US Interests (Congressional Research Service, 2014), 6-7. 
foreign policy interests worldwide has thus been confirmed." 60 The report further emphasizes that "the forms and methods the Russian intelligence services use in their work have been, to a considerable degree, inspired by the forms and methods successfully employed by the Soviet espionage in the 1980s." 61

More than seven years after the Czech report, with the lessons of Crimea, Eastern Ukraine, and flight $\mathrm{MH} 17$ fresh in the global consciousness, it appears that the forecasts made in the AMWG's final 1992 report have also been confirmed. Today, it seems certain that the Kremlin's use of active measures in foreign policy did not end with the collapse of the Soviet Union.

The use of active measures in modern Russian political warfare is merely the continuation of decades-old Soviet policy, itself a reflection of Imperial Russian methods. ${ }^{62}$ In the $21^{\text {st }}$ century, Russia has simply recycled and updated these age-old subversion techniques for use in a digitally interconnected and globalized world - the single world information area described by Soviet thinkers more than 25 years ago. ${ }^{63}$

\section{Meet the New Tricks, Same as the Old Tricks}

Although the "ends" and "ways" of Putin's active measures may be broadly analogous to those of the Soviet Era, many of the "means" have been updated for the contemporary environment. In some cases, old methods have been completely supplanted: gone are the typewriters and letter writing campaigns, replaced by view counts, retweets, and "troll factories." In other cases, old techniques are still effective, and front groups, friendship societies, and agents of influence still have their place today.

While state-sponsored media outlets like RT, Ruptly, and Sputnik are certainly part of the "information warfare blitzkrieg," analysis of their content and themes can lend vital clues to the presence of ongoing active measures in the "real world." As identified by the AMWG more than 25 years ago, then as now, Russian state-sponsored media outlets are the "white propaganda" component of a symbiotic, mutually supporting system of disinformation. In Putin's Russia, the state mechanism of subversion replicates its Soviet precursor, closely matching this description from the USIA's 1992 report:

The 'black' (KGB), 'gray' (Christian Peace Conference) [a Soviet front group], and 'white' (Novosti Press Agency) elements of the Soviet active measures apparatus worked together, weaving a seamless web that first planted and then spread the

60 Security Information Service of the Czech Republic, Annual Report of the Security Information Service (BIS) (2008), 5.

61 Ibid., 5 .

62 Schoen and Lamb, "Deception, Disinformation, and Strategic Communications," 9.

63 Soviet Active Measures in the "Post-Cold War" Era. Quote appears in section titled "New Thinking in Perspective: The Soviet View." 
messages of Soviet active measures specialists, while obscuring their role in orchestrating this campaign from start to finish. ${ }^{64}$

\section{Case Study \#1: Media Manipulation, Troll Factories, and Useful Idiots}

Our KGB staff, using new typewriters and wearing gloves so as not to leave fingerprints, typed up hundreds of anonymous hate letters and sent them to dozens of African missions. The letters, purportedly from white supremacists as well as average Americans, were filled with virulent racist diatribes. The African diplomats publicized some of the letters as examples of the racism still rampant in America, and members of the American and foreign press corps quoted from them.

$$
\text { - Oleg Kalugin, } 1994^{65}
$$

During the Cold War, one of the most widely practiced Soviet active measure techniques was the manipulation of global media through planted stories. Mainly targeting third-world audiences, the KGB followed a methodology that could be summarized as plant, incubate, and propagate.

As described in Studies in Intelligence, false stories were first developed by KGB officers as part of a larger disinformation campaign, and then planted in an easily manipulated media environment - usually in the third world. $^{67}$ The story would then be picked up by local news outlets and allowed to incubate. ${ }^{68}$ After some time, and depending on a story's "stickiness," when it had gained enough traction in smaller markets, larger Soviet press outlets would pick it up and propagate it to a wider audience. $^{69}$

While these media manipula-

In 1983, the Patriot, a pro-Soviet Indian paper that often published pieces provided by KGB agents, released a story claiming that the US military created the AIDS virus and released it as a weapon. For a couple of years, the story appeared in minor publications that were mostly KGB controlled or sympathetic to the Soviets. After this incubation period, the slander was picked up in 1985 by the official Soviet cultural weekly newspaper, the Literaturnaya Gazeta. After that, the story began to spread rapidly. In 1987 alone, it appeared over 40 times in the Soviet-controlled press and was reprinted or rebroadcast in over 80 countries in 30 languages. The AIDS virus was terrifying and not well understood at the time, so this piece of Soviet disinformation was especially damaging to the US image.

- Fletcher Schoen \& Christopher Lamb ${ }^{66}$ tion efforts were usually easy for Western audiences to recognize and dismiss, sometimes even major Western outlets were duped into propagating the stories. Even if Western outlets never picked up the story, the seeds of doubt had

64 Ibid. Quote appears in section titled "Manipulation of the Russian Orthodox Church."

65 Oleg Kalugin, Spymaster: My Thirty-Two Years in Intelligence and Espionage Against the West (New York, NY: Basic Books, 2009), originally published as The First Directorate (n.p.: St. Martin's Press, 1994), 54.

66 Schoen and Lamb, "Deception, Disinformation, and Strategic Communications," 6.

67 Boghardt, "Operation INFEKTION: Soviet Bloc," 3.

68 Ibid., 3.

69 Ibid., 3. 
been sown and, often, their rumors and conspiracy theories made their way back to the West and into public consciousness. In essence, with its Cold War media manipulation efforts, the KGB was "going viral" with its disinformation long before the Internet age.

As the now-famous meme goes, "on the Internet, no one knows you're a dog," and today it is far easier for Russian disinformation to go viral - without a legion of typewriters and a ream of stamps. ${ }^{70}$ Plant, incubate, propagate has been replaced by tweet, retweet, repeat.

For example, in an article titled, "The Agency," the New York Times sheds light on the fascinating rise of Russia's socalled "troll factories." The organization profiled in the article is based in St. Petersburg, and known as the Internet Research Agency. ${ }^{71}$ According to the article, "the agency had become known for employing hundreds of Russians to post pro-Kremlin propaganda online under fake identities, including on Twitter, in order to create the illusion of a massive army of supporters." 72 It then describes an interview with Ludmila Savchuck, former "Agency" employee turned whistleblower, who explains the workload: "Two 12-hour days in a row, followed by two days off. Over those two shifts she had to meet a quota of five political posts, 10 nonpolitical posts and 150 to 200 comments on other workers' posts." 73

According to former troll farm owner Platon Mamatov, also profiled in the article, there are "scores of operations like his around the country, working for government authorities at every level." 74 At "The Agency" in St. Petersburg, Savchuck was just one of reportedly 400 employees. ${ }^{75}$

70 “On The Internet, Nobody Knows You're a Dog," Wikipedia, https://en.wikipedia.org/ wiki/On_the_Internet,_nobody_knows_you\%27re_a_dog (accessed 19 August 2015).

71 Adrian Chen, "The Agency," The New York Times, 2 June 2015, www.nytimes.com/ 2015/06/07/magazine/the-agency.html (accessed 20 June 2015).

72 Ibid.

73 Ibid.

74 Ibid.

75 Ibid. 
The true scope of these relatively new trolling operations is unknown, and critically understudied. It would seem, though, that the troll farms accomplish a number of subversive objectives and are directly descended from several classic active measure techniques.

First, their efforts to pollute the global information space "have made it impossible for the normal Internet user to separate truth from fiction," shaping the environment for other Russian influence campaigns and messaging. ${ }^{77}$ In addition, "waves of trolls and bots regularly promote proPutin hashtags" and stories, propagating the Kremlin's message with a magnitude that was impossible before the Internet and social media age. ${ }^{78}$

While examples of social media "weaponization" are becoming

Agents of influence are foreigners who have been recruited by the KGB in order to be used to influence the opinions of foreign publics and governments. Agents of influence are extremely useful because they are perceived as loyal patriots of their respective countries who are simply expressing their own personal opinions, not scripts written by the KGB... The covert influence campaigns that they wage in public and private are not only the most difficult type of active measures operation to identify, but also potentially the most potent if the agent of influence is a senior government official or a respected public figure.

- USIA Report, Soviet Active Measures in the "Post-Cold War" Era, 1988-1991 increasingly common, a 2014 incident demonstrates how the Kremlin's hashtag propagation efforts can be amplified with the help of an American celebrity - a useful agent of influence perhaps blindly promoting the Kremlin's propaganda. Alexander Ovechkin is a renowned and immensely popular hockey player in America's National Hockey League (NHL). A Moscow native, he played a number of years for Dynamo Moscow and has been a member of the Russian National team on multiple occasions, both at World Championship events and during the Olympics. $^{79}$

In 2004 he was the NHL's number one draft pick, signed by the Washington Capitals and entering the league during the 2005-2006 season. Two years later, he signed the highest paying contract in NHL history, worth \$124 million over 13 years. ${ }^{80}$ For his achievements on the ice, he was named rookie of the year in 2006, and Most Valuable Player in 2008, 2009, and again in 2013. He currently has 365,000 Instagram followers, and more than 1.42 million on Twitter. ${ }^{81}$

76 Soviet Active Measures in the "Post-Cold War" Era. Quote appears in section titled "Agents of Influence."

77 Ibid.

78 Ibid.

79 "Alexander Ovechkin," Wikipedia, https://en.wikipedia.org/wiki/Alexander_ Ovechkin (accessed 19 August 2015).

80 lbid.

81 https://instagram.com/aleksandrovechkinofficial (accessed 19 August 2015); https://twitter.com/ovi8 (accessed 19 August 2015). 
On August $28^{\text {th }}, 2014$, he instagrammed a professional photo of himself in a t-shirt that read, "No War." In the photo, he held a sign implicitly supporting Russia's involvement in the Ukrainian conflict, bearing the hashtag, "\#SAVECHILDRENFROMFASCISM." The post received more than 17.4 thousand "likes," immediately reaching his nearly two million social media followers and garnering an even larger audience when the story was picked up by local and international media. Two weeks later (sourced

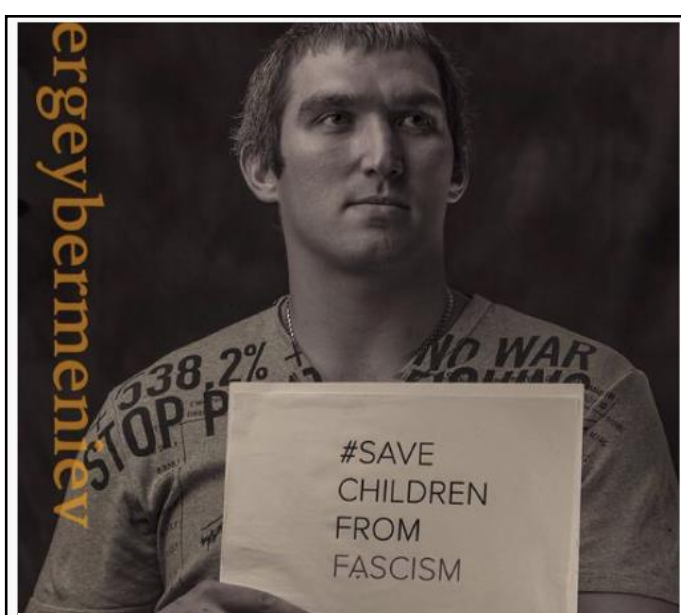

From: Official Instagram Account of Alexander Ovechkin. from RIA Novosti), the story appeared on the English-language site of Russian internet news outlet Sputnik, which bills itself as a "provider of alternate news content" and is openly financed by the Russian government. ${ }^{82}$ Sputnik's story emphasized the "strong [Western] criticism" Ovechkin received for his photo. Yet despite receiving criticism for his social media activity, Ovechkin continues to post pro-Putin content online, widely propagating the Kremlin's message and still serving as a useful tool in Russia's active measure arsenal.

\section{Case Study \#2: Driving Wedges in Western Alliances with Agents of Influ- ence and Front Groups}

A favorite strategy of Soviet active measure campaigns was to exploit rifts in Western alliances - particularly between EU and NATO member states. Russia continues to employ this strategy today. The European Council on Foreign Relations published a report in 2007 that brings some of these cracks into focus, highlighting "the EU's failure to agree on a common Russia policy" and demonstrating that this has "allowed the Kremlin to increase its leverage over the EU, through signing bilateral energy deals, playing the Kosovo card, asserting itself in the common neighbourhood, and dragging its feet on preventing nuclear proliferation." ${ }^{83}$

The report categorizes EU member states based on their stance toward Russia, singling out Greece and Cyprus as "trojan horses whose governments often

82 "Ovechkin Speaks Against Fascism in Ukraine, Faces Criticism From Americans," Sputnik News, 10 September 2014, http://sputniknews.com/world/20140910/ 192814040/Ovechkin-Speaks-Against-Fascism-in-Ukraine-Faces-Criticism-From.html (accessed 19 August 2015).

83 Mark Leonard and Nicu Popescu, A Power Audit of EU-Russia Relations (London: European Council on Foreign Relations, 2007). 
defend positions close to Russian interests, and who have been willing to veto common EU positions. The [report] also reveals little-known facts such as Cyprus being the biggest official 'investor' in Russia, due to the amount of Russian capital which is saved there." 84

Demonstrating the potential for a Russian "spoiler" within the EU, and at the very least, the manipulation of a high-level mouthpiece, in April 2015 Putin met with Greek Prime Minister Alexis Tsipras, adding to the furor over Greece's potential departure from the EU - the so-called "Grexit." Coming at a critical time in the crisis, Putin's meeting with the Prime Minister was highly controversial, as were Tsipras' comments regarding Western sanctions against Russia. Tsipras said, "we have repeatedly declared our disagreement ... this is our point of view that we constantly express to our colleagues in the EU. We don't think that this is a fruitful decision. It's practically an economic war." 85

Manipulation of political groups is a classic active measures technique, and Russia is currently influencing a number of these groups in the EU - their stagemanaged sound bites making headlines and scoring influence for the Kremlin. An article by Radio Free Europe/Radio Liberty from July 2015 highlights several concerning incidents involving French groups, likely tied to Russian active measure campaigns. In November 2015, for instance, the "far-right National Front party made headlines... when it accepted an \$11 million loan from Russian creditors following talks between its leader, Marine Le Pen, and officials in Moscow." 86 The National Front party runs on an anti-EU and anti-immigration platform, and has been called a "pro-Russian bloc inside the EU Parliament." ${ }^{87}$ In May 2014, the National Front Party became France's "top party on the European stage... polling a historic $25 \%$ of votes in the European elections." 88

In a recent, highly controversial example of Russian manipulation, a group of ten French lawmakers from the mainstream political right visited Crimea in July 2015 , becoming "the first... European delegation since the peninsula's un-

84 Ibid.

85 David M. Herszenhorn and Liz Alderman, "Putin Meets With Alexis Tsipras of Greece, Raising Eyebrows in Europe," The New York Times, 8 April 2015, www.nytimes.com/ 2015/04/09/world/europe/putin-russia-alexis-tsipras-greece-financial-crisis.html (accessed 12 August 2015).

86 Claire Bigg, "Crimea Visit Spotlights Kremlin Sympathies Beyond French Fringes," Radio Free Europe / Radio Liberty, 29 July 2015, www.rferl.org/content/crimea-visitspotlights-kremlin-sympathies-beyond-french-fringes/27159124.html (accessed 29 July 2015).

87 Luke Harding, "We Should Beware Russia's Links With Europe's Right," The Guardian, 8 December 2014, www.theguardian.com/commentisfree/2014/dec/08/russiaeurope-right-putin-front-national-eu (accessed 12 August 2015).

88 Kim Willsher, "Marine Le Pen's confidence vindicated by Front National election triumph," The Guardian, last modified 25 May 2014, www.theguardian.com/ world/2014/may/25/marine-le-pen-confidence-proves-vindicated-front-national (accessed 19 August 2015). 
recognized annexation by Russia." ${ }^{89}$ While in Crimea, the parliamentarians made a number of contentious statements, supporting Crimea's referendum on independence (note: which was deemed illegal by the EU), and stating that there was "no reason for Europe to maintain its sanctions against Russia." 90 The trip, which, according to the article, was "denounced... as a violation of international law" by the French Foreign Ministry, was organized by the FrancoRussian Dialogue Association; undoubtedly a Russian front group, and part of a "gray" active measures campaign directed against France. ${ }^{91} \mathrm{~A}$ blatant indicator, the group's co-president, Vladimir Yakunin, is a close friend of Putin's with a reported KGB past. In March 2014 he was specifically named on a US Treasury Department list of sixteen Russians targeted for individual sanctions. The Treasury's justification was as follows:

Vladimir Yakunin was appointed as chairman of the board of the Russian stateowned company Russian Railways on June 15, 2005; he has remained as head of the company ever since. Yakunin is being designated because of his official position in the Russian government, but he is also a close confidant of Putin. Yakunin regularly consults with Putin on issues regarding the Russian Railways company. In addition, Yakunin accompanies Putin on many domestic and international visits. Yakunin met Putin while both were working in St. Petersburg. Yakunin decided to create a business center in the city and contacted Putin for his support. In addition, Yakunin became a member of the board of the Baltic Maritime Steamship Company on Putin's instructions. Yakunin and Putin were also neighbors in the elite dacha community on the shore of Lake Komsomolsk and they served as cofounders of the Ozero Dacha Cooperative in November $1996 .{ }^{92}$

Yakunin is but one of Putin's many siloviki, and the Franco-Russian Dialogue Association one of countless state-sponsored friendship groups and discussion clubs. With innocuous-sounding names, similar groups such as the Valdai Discussion Club and many others remain a highly effective tool for manipulating public opinion and amplifying Kremlin messaging. ${ }^{93}$

\section{Case Study \#3: Defending the Cash Cow with Front Groups, Espionage, and the Media}

Russia is a rentier state, with its energy sector alone providing " $20-25$ percent of GDP, 65 percent of total exports and 30 percent of [the] government

89 Bigg, "Crimea Visit Spotlights Kremlin."

90 Ibid.

91 Ibid.

92 "Treasury Sanctions Russian Officials, Members of the Russian Leadership's Inner Circle, And An Entity For Involvement In The Situation In Ukraine," Press Center: US Department Of The Treasury, March 20, 2014, accessed August 12, 2015, http://www.treasury.gov/press-center/press-releases/Pages/jl23331.aspx.

93 Amid controversy, in August 2015 Yakunin stepped down as head of Russian Railways to become a senator representing the Kaliningrad region. In October 2015, he announced plans to launch a policy focused global think tank. 
budget." ${ }^{94}$ In 2015, low oil prices devastated the one-dimensional Russian economy. ${ }^{95}$ With a lack of economic diversity, any disruptions to Russia's energy revenues are a serious threat - and America's emerging fracking industry is a big one. Detailed in a recent article in the National Review, Russia has undertaken a "three-pronged strategy" to weaken the rapidly developing US fracking industry. ${ }^{96}$ According to the article, Russia is using a combination of classic active measures, including: "covert payments to environmental groups in the West," and espionage directed at the "American energy industry." ${ }^{97}$ The report further describes an ongoing case with the US Justice Department, in which three agents of the Russian Foreign Intelligence Service (SVR) were charged "with spying on United States' efforts to develop alternative energy resources." ${ }^{98}$

In support of these active measures, the campaign is constantly reinforced by state-sponsored propaganda, led by RT, which "recently released an hourlong documentary that 'documents' illnesses supposedly induced by fracking in the American heartland." ${ }^{99}$ Similar active measures against fracking are likely to continue, with the Russian Orthodox Church potentially joining the fray and voicing concerns over the environmental impact of hydraulic fracturing.

\section{Conclusion}

Don't say, "We need another reset with Russia." And I'm the guy that said that to the president the last time around in the Oval Office.

- Michael McFaul, former US Ambassador to Russia, $2015^{100}$

Toward the end of the Cold War, NSDD 75 and the Reagan Doctrine provided clear, overarching strategic guidance for the whole of American government a "single sheet of music" to synchronize the US approach to the Soviet Union. Today, no such guiding document exists for American policy toward the Russian Federation. While a nuclear-armed Russia may not pose the same existential threat to the United States that the Soviet Union once did, the current lack of a

94 "Key Macroeconomic Indicators," Ministry of Economic Development of the Russian Federation, http://www.ved.gov.ru/eng/general/economy/ (accessed 12 August 2015).

95 Anna Andrianova, "Russian GDP Plunges 4.6\%," Bloomberg Business, 10 August 2015, http://www.bloomberg.com/news/articles/2015-08-10/russian-economy-shrinks-46-as-oil-slump-risks-deeper-recession (accessed 12 August 2015).

96 Tom Rogan, "Russia's War on Fracking," National Review, 3 February 2015, http://www.nationalreview.com/article/397755/russias-war-fracking-tom-rogan (accessed 24 June 2015).

97 Ibid.

98 Ibid.

99 Ibid.

${ }^{100}$ Olivier Knox, “Russia 'Reset' Architect to Next President: Don't Try That Again," Yahoo Politics, 28 May 2015, https://www.yahoo.com/politics/russia-reset-architectto-next-president-dont-120051660936.html (accessed 9 July 2015). 
US strategy for Russia promotes confusion among the agencies and inhibits unity of effort in shaping an American response to Russian aggression. ${ }^{101}$ With US policy left up to interpretation by individual actors, and without a cogent, definable end state, a disjointed, ineffective response and wasteful spending are likely outcomes. Additionally, lacking a united front, seams between government branches and agencies present themselves for exploitation. As described in a survey of the power relationship between the EU and Russia, for the EU's 28 member states defining a common strategy toward Russia is an even greater challenge, and, likely, next to impossible. ${ }^{102}$

Russia is the world's largest country and borders five EU member states. Its military is nearly 800,000-strong, with an estimated 20,000 tanks and more than 1,300 aircraft. ${ }^{103}$ It possesses an estimated 7,500 nuclear warheads, and is training with Iskander tactical nuclear missiles in Kaliningrad. ${ }^{104}$ With Putin potentially in office for another nine years, and the "reset" experiment now considered a failure, the US and others must develop a comprehensive strategy for dealing with Russia. ${ }^{105}$ Without clear "ends," it is not possible to establish effective "ways" and "means."

Despite the lack of a defined US strategy, a number of think tanks and military leaders are discussing new approaches to a future that will increasingly involve the use of "hybrid warfare." One of these concepts, the so-called "third offset" strategy, envisions a future where "US capability advantages...[in] unmanned operations, extended-range and low observable air operations, undersea warfare, and complex system engineering, integration, and operation ... could be leveraged to form a global surveillance and strike (GSS) network." 106 The strategy envisages a network of interconnected, autonomous stealth drones, unmanned undersea vehicles, underwater "payload" stockpiles, highenergy lasers, and counter-space capabilities. ${ }^{107}$ This strategy is designed to offset the post-Cold War gains of potential adversaries, and allow the US to maintain military superiority well into the future. Proponents of this third-offset acknowledge, however, that it will not be a panacea. This incredibly expensive

${ }^{101}$ Crawford, "Joint Chiefs Nominee."

102 Leonard and Popescu, A Power Audit of EU-Russia.

103 Jonathan Masters, "The Russian Military," Council on Foreign Relations, 20 March 2015, http://www.cfr.org/russian-federation/russian-military/p33758.

104 "Status of World Nuclear Forces," Federation of American Scientists (FAS), http://fas.org/issues/nuclear-weapons/status-world-nuclear-forces/ (accessed 17 August 2015); Vladimir Isachenkov, "Russia Is Putting State-of-the-Art Missiles in Its Westernmost Baltic Exclave," Business Insider, 18 March 2015, www.businessinsider.com/russia-placing-state-of-the-art-missiles-in-kaliningrad2015-3?op=1 (accessed 17 August 2015).

${ }^{105}$ Knox, "Russia 'Reset' Architect."

${ }^{106}$ Robert Martinage, Toward a New Offset Strategy: Exploiting U.S. Long-Term Advantages to Restore U.S. Global Power Projection Capability (Center for Strategic and Budgetary Assessments, 2014), ii, v.

107 Ibid. 
effort will not address a number of fundamental changes taking place in our increasingly globalized society.

Many experts believe that the nature of warfare has undergone a dramatic shift, and future conflicts will be dramatically different than in the past. As Thomas Nissen of the Royal Danish Defence College explains, "War is no longer about states against states (in the conventional sense), but about identity and identity claims, and about cosmopolitanism (inclusion) versus particularism (exclusion/nationalism). Contemporary wars are therefore more about control of the population and the political decision-making process than about control over territory." 108

Recent Chinese and Russian military doctrines bear out this theory, making it clear that the global information space will be the battlefield of the future with conflicts won and lost in phase zero of the conflict spectrum. China's "three warfares" strategy relies on "legal warfare, media warfare, and psychological warfare," and Russia's so-called "Gerasimov Doctrine" promotes "the broad use of political, economic, informational, humanitarian and other nonmilitary measures." ${ }^{109}$ With this in mind, it is extremely likely that use of subversion and active measure campaigns will only increase in the future. It is essential that the US and its allies recognize this threat, and rapidly develop solutions to counter it.

\section{Recommendations}

In their report, The Menace of Unreality, Peter Pomerantsev and Michael Weiss acknowledge the escalating trend of information weaponization, proposing a number of insightful strategies to combat the effectiveness of coordinated disinformation and propaganda campaigns. Likewise, writing for NATO in a draft report on countering propaganda, reporter Witold Waszczykowski offers a series of suggestions for the Alliance. ${ }^{110}$

While Pomerantsev and Weiss acknowledge the contributions of the AMWG, they also understand the limitations of a Cold War approach and methodology in today's connected world. ${ }^{111}$ Despite this, however, the group's experiences still offer a number of critical lessons and best practices for future government efforts to combat active measures and disinformation. Just as ageold Soviet techniques have been modernized through updated "means," the

\footnotetext{
${ }^{108}$ Thomas E. Nissen, The Weaponization of Social Media (Copenhagen, Denmark: Royal Danish Defense College, 2015) 8.

${ }^{109}$ Timothy A. Walton, China's Three Warfares (Herndon, VA: Delex Systems, 2012); Sam Jones, "Ukraine: Russia's New Art of War," Financial Times, 28 August 2014, www.ft.com/cms/s/2/ea5e82fa-2e0c-11e4-b760-00144feabdc0.html (accessed 17 August 2015).

${ }^{110}$ Witold Waszczykowski, The Battle For The Hearts and Minds: Countering Propaganda Attacks Against the Euro-Atlantic Community (NATO Parliamentary Assembly, Committee on the Civil Dimension of Security, 2015).

${ }^{111}$ Pomerantsev and Weiss, The Menace of Unreality, 41.
} 
lessons of the AMWG can be similarly adapted, leveraging technology for greater collaboration, communication, and responsiveness than ever before.

A number of these lessons, along with the recommendations, are reproduced below. Any future effort to expose the active measures of potential adversaries should start with a thorough reading of these outstanding publications, for the first step in exposing an active measures campaign is awareness that the problem exists. Today, that awareness is sorely lacking.

\section{Adapted from Pomerantsev \& Weiss, The Menace of Unreality}

Recommendations for countering the weaponization of information:

- Establish a "Transparency International" for disinformation

- Establish a "Disinformation Charter" for media and bloggers

- Establish/ hire "counter-disinformation editors" for media outlets

- Better public awareness campaigns about the use/spread of propaganda, and improved disclosure of personal interests by think tanks, pundits, etc.

- Targeted online work to assist those affected by intense propaganda: equivalent of online social work for those in heavily impacted areas.

Recommendations for countering the weaponization of money:

- Establish organizations and non-profit funding streams to support the journalistic investigation of corruption (Strategic Corruption Research). Establish a Journalist's Libel Fund to protect investigative journalists from vengeful lawsuits

- Support crowd-sourced investigative efforts to uncover corruption and/or propaganda, with NGO's as a vector.

Recommendations for countering the weaponization of ideas:

- Re-establishing transparency and integrity among think tanks and others: encourage self-disclosure of funding streams

- Establish a "Valdai Alternative" to counter the challenges posed by Valdai, Kremlin-friendly NGOs and the use of the Orthodox Church. Would bring together think tanks, experts and policy makers to help reinvigorate debate about the implications of Russian policy for both regional and global issues.

\section{Adapted from Witold Waszczykowski's Draft NATO "Report on Countering Propaganda Attacks against the Euro-Atlantic Community"}

- Countering Russia's information warfare should be elevated to the top of the Euro-Atlantic community's agenda

- Within the framework of the NATO Parliamentary Assembly, it is necessary to authorize a specific Sub-Committee or another Assembly body to constantly monitor the evolution of this threat and to report to the Assembly on this issue on a regular basis 
- Develop a more coherent narrative and a set of arguments refuting myths cultivated by Moscow, following up on NATO's Setting the Record Straight example.

- Further reinforcing NATO's Public Diplomacy Division (PDD) and relevant bodies in the EU to enhance the ability to respond swiftly to the most blatant cases of misinformation

- Policy towards classified intelligence information should be revisited to allow public diplomacy officers to use less sensitive information, including satellite imagery, in order to refute misinformation

- Establish platforms for exchanging best national practices among the EuroAtlantic community and flagging potential information security threats

- Revisit legislation that strengthens legal counter-measures such as imposing fines for the use of hate speech and clear disinformation

- Encourage the world's leading media outlets to develop a set of high journalistic standards and encourage independent global watchdogs to monitor how these standards are being maintained

- Support international and national media initiatives in the Russian language, including launching a commonly funded Russian-language TV channel

- Revisit legislation to increase the transparency of funding media, NGOs and think tanks

- Make a clear distinction between Russian journalists, however biased, and propagandists repeatedly involved in distorting and fabricating information

- Apply individual travel sanctions against the most active propagandists and political technologists

- Consider innovative and inexpensive measures such as the greater use of humor: launching a TV show or a section in a newspaper that depicts and ridicules the most awkward cases of the falsification of information

- Invest in research and educate the appropriate people as to how to recognize, report and react to Internet trolls and orchestrated "trolling" attacks

- Increase capacity building assistance to countries like Ukraine in the field of strategic communications

- Organize surveys to regularly monitor the effect of Russian propaganda on the populations within the Euro-Atlantic space

- Encourage and promote the voices of popular Russian diaspora representatives with democratic views

- Support the community of professional historians to provide credible response to pseudo-scientific theories that glorify Stalinism, belittle the statehood of Russia's neighbors and falsify historical facts

- Encourage grassroots initiatives such as StopFake.org. 
Lessons Learned by the Active Measures Working Group, adapted from Schoen and Lamb's, "Deception, Disinformation, and Strategic Communications: How One Interagency Group Made a Major Difference"

The AMWG operated using a Report, Analyze, Publicize methodology:

- Report: Received and combined reports from USIA posts around the world, the $\mathrm{CIA}$, and FBI investigations (note: today, the USIA function could be replaced with enhanced support by Embassy Public Affairs teams)

- Analyze: Analysis took place in D.C.; group members came from across the Interagency and generally met weekly. Attendance varied and members rotated in and out based upon requirements at their 'day-jobs'

- Publicize: The group produced semi-regular reports on Soviet disinformation. The reports were unclassified and circulated throughout the Interagency and to the press. The group also developed a 'road show' to help educate personnel at Embassies, as well as host nation intelligence services and members of the host nation media

- By publishing their reports and conducting road shows, the group raised awareness, which led to a virtuous cycle of reporting. The more they publicized Soviet disinformation efforts, the more frequent and better reports they received from the field.

The AMWG stayed focused preventing 'mission creep' by defining a limited set of targets:

- It limited its mission to countering Soviet influence operations that could be exposed in a compelling way with unclassified or declassified information

- This methodology allowed it to concentrate on cases that were likely "winners"

- Remained focused on exposing disinformation (outright lies) rather than propaganda (persuasion).

The AMWG's approach to countering active measures included, critically:

- Effective counterintelligence

- Persistent and continuing exposure of disinformation

- Maintaining the highest standards of accuracy

- Maintaining an unimpeachable record of accuracy and trustworthiness, which allowed the group to remain credible (held their products to an internal, 'grand jury indictment standard,' setting extremely high internal standards to ensure their reports on Soviet disinformation were air-tight and impossible to pick apart)

- Worked to expose Soviet lies not in an ideological but professional fashion.

The Department of State was the AMWG's lead agency: 
- Gave the group diplomatic credibility

- Helped ensure the group's efforts were managed with political sensitivity.

Senior leader support and protection was necessary for the working group's continued existence and success:

- The group had supporters at all levels of the executive branch

- Congressional leaders generated requirements, promoted group members, and lobbied for institutionalized capability to produce the reports

- The group also needed strong leadership to maintain effectiveness:

- Having a Deputy Assistant Secretary of State lead the group was effective

- Political appointees in positions of authority helped provide top cover.

The AMWG was an inexpensive solution to countering Soviet disinformation. The costs of exposing Soviet disinformation were insignificant compared to what the Soviets spent to create and distribute it:

- Producing high quality results with few resources made cooperation from parent organizations more likely

- The group had no mission-specific resources:

- It drew only on the part-time contributions of existing experts and inplace State Intelligence analysts to cover manpower costs

- Members had no budgets beyond normal travel and public affairs accounts controlled by their bosses.

The declassification of Interagency reporting and other evidence was essential to the group's success, providing the solid 'proof' they needed to support their 'cases':

- Declassification was contentious however: information sharing did not always occur due to parent agency concerns regarding the exposure of sensitive sources and methods.

Among the members of the group, expertise and a mission focused attitude were valued above rank.

\section{About the author}

Steve Abrams is a Russian-speaking US Army Foreign Area Officer specializing in the Eurasian region. He is currently pursuing a Master's Degree in Conflict Management at the Johns Hopkins School of Advanced International Studies in Washington, DC. E-mail: abrams.steve@gmail.com. 


\section{Bibliography}

Alexander Ovechkin. Wikipedia, 2015, https://en.wikipedia.org/wiki/ Alexander_Ovechkin.

Allen, Richard V. The Man Who Won the Cold War. Hoover Digest, 2000, http://www.hoover.org/research/man-who-won-cold-war.

Andrianova, Anna. Russian GDP Plunges 4.6\%. Bloomberg Business, 2015, http://www.bloomberg.com/news/articles/2015-08-10/russian-economyshrinks-4-6-as-oil-slump-risks-deeper-recession.

Annual Report of the Security Information Service (BIS)., 2008.

Asada, Matthew, Susan Johnson, and Cameron Munter. Diplomacy Post-9/11: Life in the US Foreign Service, In interview by Kojo Nnamdi, The Kojo Nnamdi Show., 2011, http://thekojonnamdishow.org/shows/2011-09-22/diplomacypost-911-life-us-foreign-service.

Bailey, Norman A. The Strategic Plan That Won the Cold War: National Security Decision Directive 75. MacLean, VA: The Potomac Foundation, 1998.

Bigg, Claire. Crimea Visit Spotlights Kremlin Sympathies Beyond French Fringes. Radio Free Europe / Radio Liberty, 2015, www.rferl.org/content/crimea-visitspotlights-kremlin-sympathies-beyond-french-fringes/27159124.html.

Bigg, Claire. Crimea Visit Spotlights Kremlin Sympathies Beyond French Fringes. Radio Free Europe / Radio Liberty, 2015, www.rferl.org/content/crimea-visitspotlights-kremlin-sympathies-beyond-french-fringes/27159124.html.

Birnbaum, Michael. "Fearing Russian Expansion, Baltic Nations Step Up Military Exercises." The Washington Post (2015), www.washingtonpost.com/world/ europe/fearing-russian-expansion-baltic-nations-step-up-military-exercises/ 2015/05/15/b5ee51ee-f8c8-11e4-a47c-e56f4db884ed_story.html.

Boghardt, Thomas. "Operation INFEKTION: Soviet Bloc Intelligence and Its AIDS Disinformation Campaign." Studies in Intelligence 53, no. 4 (2009): 1-2.

Bourdieu, Cf. Pierre. "Forms of Capital." In Cultural Theory: An Anthology, 81-93. Imre Szeman and Timothy Kaposy ed. Oxford: Wiley-Blackwell, 2011.

Chen, Adrian. "The Agency." The New York Times (2015), www.nytimes.com/ 2015/06/07/magazine/the-agency.html.

Crash of Malaysia Airlines Flight Mh17, In The Hague: Dutch Safety Board. Dutch Safety Board, 2015, http://onderzoeksraad.nl/en/onderzoek/2049/ investigation-crash-mh17-17-july-2014.

Crawford, Jamie. Joint Chiefs Nominee: Russia Greatest Threat to U.S. CNN Politics, 2015, www.cnn.com/2015/07/09/politics/joseph-dunford-russiagreatest-threat/index.html. 
Crozier, Brian. "The Other Side of Perestroika: The Hidden Dimension of the Gorbachev Era."Demokratizatsiya 4, no. 1 (1996): 48-49.

Derluguian, Georgi M. Bourdieu's Secret Admirer in the Caucasus: A WorldSystem Biography . Chicago: University of Chicago Press, 2005.

Derluguian, Georgi M. Bourdieu's Secret Admirer in the Caucasus: A WorldSystem Biography . Chicago: University of Chicago Press, 2005.

Derluguian, Georgi M., and et al. Adept Bourdieu in the Caucasus. Sketches for the Biography in the World-System Perspective . Directmedia, 2013.

Gertz, Bill. Washington Times (2015), http://www.washingtontimes.com/ news/2015/apr/29/inside-the-ring-house-funding-bill-targets-russian/?

Gessen, Cf. Masha. The Man Without a Face: The Unlikely Rise of Vladimir Putin. New York: Riverhead, 2012.

Gessen, Masha. Portrait of the Young Vladimir Putin. Newsweek, 2012, www.newsweek.com/portrait-young-vladimir-putin-65739.

Harding, Luke. "We Should Beware Russia's Links With Europe's Right." The Guardian (2014), www.theguardian.com/commentisfree/2014/dec/08/russiaeurope-right-putin-front-national-eu.

Herszenhorn, David M., and Liz Alderman. Putin Meets With Alexis Tsipras of Greece, Raising Eyebrows in Europe. The New York Times, 2015, www.nytimes.com/2015/04/09/world/europe/putin-russia-alexis-tsiprasgreece-financial-crisis.html.

Illarionov, Andrei. "The Siloviki in Charge." Journal of Democracy 20, no. 2 (2009): 70-71.

Inside the KGB - An interview with retired KGB Maj. Gen. Oleg Kalugin, Cold War Experience. CNN, 1998, http://web.archive.org/web/20070627183623/ http://www3.cnn.com/SPECIALS/cold.war/episodes/21/interviews/kalugin.

Isachenkov, Vladimir. Russia Is Putting State-of-the-Art Missiles in Its Westernmost Baltic Exclave. Business Insider, 2015, www.businessinsider.com/ russia-placing-state-of-the-art-missiles-in-kaliningrad-2015-3?op=1.

Johnston, Ian. "'Russia's Growing Threat: After Ukraine, Fears Grow That Baltic States Could Be Vladimir Putin's Next Targets." The Independent(2015), http://www.independent.co.uk/news/world/europe/russias-growing-threatafter-ukraine-fears-grow-that-baltic-states-could-be-vladimir-putins-nexttargets-10032378.htm.

Jones, Sam. "Ukraine: Russia's New Art of War." Financial Times (2014), www.ft.com/cms/s/2/ea5e82fa-2e0c-11e4-b760-00144feabdc0.html. 
Kalugin, Oleg. Spymaster: My Thirty-Two Years in Intelligence and Espionage Against the West. New York, NY: Basic Books, 2009.

Key Macroeconomic Indicators. Ministry of Economic Development of the Russian Federation, 2015, http://www.ved.gov.ru/eng/general/economy/.

Kux, Dennis. "Soviet Active Measures and Disinformation: Overview and Assessment."Parameters, Journal of the US Army War College 15, no. 4 (1985): 19.

Leonard, Mark, and Nicu Popescu. A Power Audit of EU-Russia Relations. London: European Council on Foreign Relations, 2007.

Lithuania to Ban Russian TV Channel for 'Warmongering'. Deutsche Welle, 2015, http://www.dw.com/en/lithuania-to-ban-russian-tv-channel-forwarmongering/a-18370852.

Martinage, Robert. Toward a New Offset Strategy: Exploiting U.S. Long-Term Advantages to Restore U.S. Global Power Projection Capability. Center for Strategic and Budgetary Assessments, 2014.

Meloen, Jos D., L. Hagendoorn, Q. Raaijmakers, and L. Visser. "Authoritarianism and the Revival of Political Racism: Reassessments in the Netherlands of the Reliability and Validity of the Concept of Authoritarianism by Adorno." Political Psychology 9 (1988), www.nytimes.com/2015/04/09/world/europe/putinrussia-alexis-tsipras-greece-financial-crisis.html.

Miller, Nick. MH17 Plane Was Shot Down by a Buk Missile, Russian Weapons Manufacturer Says. The Age, 2015, www.theage.com.au/world/mh17-planewas-shot-down-by-a-buk-missile-russian-weapons-manufacturer-says20150602-ghfdco.html.

Nemtsova, Anna. A Chill in the Moscow Air. Newsweek, 2006, http://www.newsweek.com/chill-moscow-air-113415.

Nichol, Jim. Russian Political, Economic, and Security Issues and US Interests. Congressional Research Service, 2014.

Nissen, Thomas E. The Weaponization of Social Media. Copenhagen, Denmark: Royal Danish Defense College, 2015.

On The Internet, Nobody Knows You're a Dog. Wikipedia, 2015, https://en.wikipedia.org/wiki/On_the_Internet,_nobody_knows_you\%27re_a_ dog.

Operation Atlantic Resolve Fact Sheet. US European Command Communication and Engagement Directorate, 2015.

Ovechkin Speaks Against Fascism in Ukraine, Faces Criticism From Americans. Sputnik News, 2014, http://sputniknews.com/world/20140910/192814040/ Ovechkin-Speaks-Against-Fascism-in-Ukraine-Faces-Criticism-From.html. 
Pulkki, Arto. "Crimea Invaded by High Readiness Forces of the Russian Federation." Suomen Sotilas (2014).

Remnick, David. "Watching the Eclipse." The New Yorker (2014), http://www.newyorker.com/magazine/2014/08/11/watching-eclipse.

Remnick, David. The Menace of Unreality: How the Kremlin Weaponizes Information, Culture and Money. New York, NY: The Institute of Modern Russia, 2014.

Russia 2000 Part 2: The Face of Russia to Come. Stratfor Global Intelligence, 1999, https://www.stratfor.com/sample/analysis/russia-2000-part-2-face-russia-come.

Russia: Expert Eyes Security Ties Among Siloviki. Radio Free Europe / Radio Liberty, 2015, http://www.rferl.org/content/article/1073593.html.

Schoen, Fletcher, and Christopher J. Lamb. Deception, Disinformation, and Strategic Communications: How One Interagency Group Made a Major Difference. Washington, DC: National Defense University Press, 2012.

Schreck, Carl. Russian TV Deserters Divulge Details On Kremlin's Ukraine 'Propaganda'. Radio Free Europe / Radio Liberty, 2015, www.rferl.org/content/ russian-television-whistleblowers-kremlin-propaganda/27178109.html.

Soviet Active Measures in the "Post-Cold War" Era. Washington, D.C.: United States Information Agency, 1992, http://intellit.muskingum.edu/russia_folder/ pcw_era/index.htm\#Contents.

Soviet Active Measures. In YouTube video, 23:31. PublicResourceOrg, 2010, https://www.youtube.com/watch?v=Z-X_bXL2Tgo.

Status of World Nuclear Forces. Federation of American Scientists (FAS), 2015, http://fas.org/issues/nuclear-weapons/status-world-nuclear-forces/.

The Making of a Neo-KGB State. The Economist (2007), http://www.economist.com/node/9682621.

Treasury Sanctions Russian Officials, Members of the Russian Leadership's Inner Circle, And An Entity For Involvement In The Situation In Ukraine. Press Center: US Department Of The Treasury, 2014, http://www.treasury.gov/presscenter/press-releases/Pages/jl23331.aspx.

Ukraine Crisis: Russia and Sanctions. BBC News, 2014, http://www.bbc.com/ news/world-europe-26672800.

Vladimir Putin: Biography. Vladimir Putin Personal Website, 2015, http://eng.putin.kremlin.ru/bio.

Walton, Timothy A. China's Three Warfares. Herndon, VA: Delex Systems, 2012. 


\section{Steve Abrams, Connections QJ 15, no. 1 (2016): 5-31}

Waszczykowski, Witold. "The Battle For The Hearts and Minds: Countering Propaganda Attacks Against the Euro-Atlantic Community." In NATO Parliamentary Assembly, Committee on the Civil Dimension of Security, 2015.

Wikileaks: Russia Branded 'Mafia State' in Cables. BBC News, 2010, http://www.bbc.com/news/world-us-canada-11893886.

Willsher, Kim. "Marine Le Pen's confidence vindicated by Front National election triumph." The Guardian (2014), www.theguardian.com/world/2014/ may/25/marine-le-pen-confidence-proves-vindicated-front-national. 